\title{
Description of Snakebite's Prevention Efforts towards Farmers in Panti Sub-District
}

\author{
Rismawan Adi Yunanto ${ }^{*}$, Wantiyah Wantiyah², Yusuf Gito Afandi ${ }^{3}$
}

1,2Department of Surgical Nursing, University of Jember, Indonesia; rismawanadi@unej.ac.id (Corresponding Author) ${ }^{3}$ Nursing Student, Faculty of Nursing, University of Jember, Indonesia

\section{Article Info: \\ Submitted: \\ 05-08-2021 \\ Revised: \\ 27-12-2021 \\ Accepted: \\ 28-12-2021}

DOI:

https://doi.org/10.53713/nhs.v1i3.48

\section{(c) (1) (2)}

This work is licensed

under CC BY-SA License.

\begin{abstract}
The knowledge toward snakebite prevention was related to preventive measures taken by farmers. Besides, a lack of farmer's awareness about the importance of using personal protective equipment and a lack of public understanding regarding the level of danger and the types of venomous snakes were factors that cause snakebites. This study aimed to describe the efforts to prevent snakebite on farmers in Panti subdistrict. The method used a quantitative descriptive with survey research design. This research was conducted on farmers in Panti with a sample of 100 respondents using cluster sampling technique. The results of this study showed respondents have known tree crevices, earthen holes, piles of wood, garbage, and twigs that are at risk of becoming snake habitats, use boots and trousers while working, maximize lighting using a lamp or flashlight, regularly mow grass and shrubs, clean up scattered leaves, and rest on higher ground when at home or in the fields. While only a few respondents participated in health education and counselling regarding snake bites. This study concluded that the majority of respondents conducted efforts to prevent snakebites.
\end{abstract}

Keywords: snakebite; prevention; farmer

\section{INTRODUCTION}

Snakebite or snakebite is one of the dangers of health factors that are included in biological hazards and often occurs in Indonesia which has a tropical climate so that they have a high risk of being bitten by snakes, especially people who work in the agricultural and plantation sectors (WHO, 2016; Rifaie et al., 2017).

Southeast Asia is the most affected region with the number of cases of venomous snake bites ranging from $111,000-498,000$ cases every year due to its high population density, large agricultural activity, many types of venomous snakes and the lack of control programs made (Putra, 2019). Indonesia is the largest tropical country with a fairly high number of snakebite cases. Estimated snake bite cases in 2007 were 12,739 - 214,883 with 2000 - 11,581 deaths (Wintoko and Prameswari, 2020). For snakebite cases in Jember Regency, especially in Panti District, it was recorded that throughout 2019 there were 8 cases of snake bites with the types of snakes reported, namely green snakes, earth snakes, and weling snakes. Then within 1 year on average there are up to 10 cases of snake bites at the Panti Health Center (Munawwaro, 2020).

Preventive measures taken by farmers in South Asia were still lacking due to the high level of illiteracy and lack of public awareness so that snakebite cases occurred around $60-80 \%$ in most farmers aged around 30-50 years. (Ralph et al., 2019). Lack of public understanding regarding the types of venomous snakes and the level of danger from snakes is also one of the factors that cause snakebites. As many as $57.2 \%$ of respondents said the place where they were bitten by snakes was in the rice fields, then $22.8 \%$ in the garden or field, $14.3 \%$ in the yard of the house, and $5.7 \%$ in the house (Afni and Sani, 2020). In Jember, there are several cases of snakebite victims. Most snakebite victims were male and were farmers. Most of the victims were bitten in the legs/feet and more of them were identified as a green snake (Yunanto and Sulistyorini, 2021). Based on the problems above, so the authors are interested in conducting research on the description related to snakebite prevention efforts towards farmers in Panti Sub-District, Jember, Indonesia.

\section{METHOD}

The research design used is descriptive quantitative method with a survey research design. This research was conducted on farmers in Panti Sub-District with a total sample of 100 respondents using cluster sampling technique. The data collection tool used is a questionnaire adapted from the research of Michael et al., (2018) as well as a derivative of 
the WHO Guidelines (2016) which have been modified by researchers to adapt to the conditions at the research site. This research has been conducted an ethical test at the Health Research Ethics Committee (KEPK) of the Faculty of Nursing, University of Jember with certificate number 94/UN25.1.14/KEPK/2021.

\section{RESULT}

\section{Characteristics of Farmers Living in Panti Sub-District}

Table 1. Characteristics of age and length of work

\begin{tabular}{lcccc}
\hline \multicolumn{1}{c}{ Characteristics } & Mean & Std. Dev & Median & Min-Max \\
\hline Age & 41.01 & 11.14 & - & - \\
\hline Long time working as a farmer & - & - & 12 & $1-40$ \\
\hline
\end{tabular}

The results of this study seen from Table 1 that the average age of the respondents is 41 years with a standard deviation of 11.14. For the variable length of service, respondents in this study obtained a median value of 12 years with the shortest working period as a farmer, 1 year and the longest being 40 years.

Table 2. Characteristics of respondents based on gender, address, ethnicity, and last education

\begin{tabular}{lcc}
\hline \multicolumn{1}{c}{ Characteristics } & Frequency $(\mathrm{n})$ & Percentage $(\%)$ \\
\hline Gender & & \\
Male & 85 & 85.0 \\
Female & 15 & 15.0 \\
\hline Address & 32 & \\
Panti & 18 & 32.0 \\
Serut & 31 & 18.0 \\
Suci & 19 & 31.0 \\
Glagahwero & & 19.0 \\
\hline Ethnicity & 87 & \\
Java & 13 & 87.0 \\
Madura & & 13.0 \\
\hline Education & 4 & \\
$\quad$ No school & 22 & 4.0 \\
Elementary School & 21 & 22.0 \\
Junior High School & 40 & 21.0 \\
Senior High School & 13 & 40.0 \\
Bachelor & & 13.0 \\
\hline
\end{tabular}

In this study, it can be seen in table 2 that the majority of respondents are male with a total of 85 people $(85 \%)$ and the rest are female with the respondent's address being mostly from Panti village, then Suci Village, Glagahwero Village, and the least from Serut Village according to the distribution of samples used by researchers. Then the majority of respondents in this study were Javanese with a total of 87 people (87\%) and the rest were Madurese with the highest level of education, namely 40 people (40\%) with the last education of high school and only 4 people (4\%) who did not go to school. 


\section{Overview of snakebite prevention efforts on farmers in Panti Sub-District}

The results of research efforts to prevent snake bites on farmers in the sub-district of the orphanage are as follows:

Table 3. Frequency and percentage of indicators to identify the habitat of snakes

\begin{tabular}{clccc}
\hline No & \multicolumn{1}{c}{ Question } & Yes & No & Don't know \\
\hline 4 & $\begin{array}{l}\text { Do you avoid putting your hands/feet into holes when working in the fields/rice } \\
\text { fields/gardens? (holes in the ground and trees) }\end{array}$ & $90(90 \%)$ & $9(9 \%)$ & $1(1 \%)$ \\
\hline 5 & $\begin{array}{l}\text { Do you avoid putting your hands/feet into the cracks/pile of wood when working } \\
\text { in the fields/rice fields/gardens?? (piles of wood, trash, twig gaps) }\end{array}$ & $91(91 \%)$ & $7(7 \%)$ & $2(2 \%)$ \\
\hline 6 & I hold/touch the snake directly & $82(82 \%)$ & $16(16 \%)$ & $2(2 \%)$ \\
\hline 10 & Do you raise livestock in the garden? (birds and rodents) & $35(35 \%)$ & $65(65 \%)$ & $0(0 \%)$ \\
\hline 14 & Do you already have your own latrine/bathroom at home? & $85(85 \%)$ & $15(15 \%)$ & $0(0 \%)$ \\
\hline 15 & Are there public toilets and toilets where you work? (rice fields, fields, gardens) & $65(65 \%)$ & $33(33 \%)$ & $2(2 \%)$ \\
\hline 17 & Do you defecate in the river? & $40(40 \%)$ & $59(59 \%)$ & $1(1 \%)$ \\
\hline 20 & Have you ever seen snakes around your environment/work place? & $91(91 \%)$ & $8(8 \%)$ & $1(1 \%)$ \\
\hline 26 & Is there a fence or barrier between the garden/rice field/field and your home & $31(31 \%)$ & $69(69 \%)$ & $0(0 \%)$ \\
& area? & & & \\
\hline
\end{tabular}

Based on table 3 above, the first indicator of snakebite prevention efforts, namely recognizing snake habitat, there are 9 question items, the results show that most of the respondents are able to recognize snake habitat. It can be seen from the efforts that are best understood by respondents in question items number 5 and 20 which state that 91 $(91 \%)$ farmers avoid putting their hands/feet into gaps/pile of wood when working in fields, rice fields, and gardens because they have seen snakes. around the environment/where they work and the remaining $7(7 \%)$ answered no. For the lowest effort, it can be seen from the respondents' answers to question number 26 , namely $69(69 \%)$ respondents said that there were no fences or barriers between gardens, rice fields, and fields with the house area.

Table 4. Frequency and percentage of indicators wearing PPE

\begin{tabular}{clccc}
\hline No & \multicolumn{1}{c}{ Question } & Yes & No & Don't know \\
\hline 3 & $\begin{array}{l}\text { Do you wear protective shoes (boots) when doing activities/working in the } \\
\text { fields/rice fields/gardens? }\end{array}$ & $94(94 \%)$ & $6(6 \%)$ & $0(0 \%)$ \\
\hline 19 & $\begin{array}{l}\text { Do you use a stick to avoid snakes when you are outside at night? (to the } \\
\text { fields/gardens/fields) }\end{array}$ & $77(77 \%)$ & $22(22 \%)$ & $1(1 \%)$ \\
\hline 23 & $\begin{array}{l}\text { Do you use a stick to avoid snakes when you are outside at night? (to the } \\
\text { fields/gardens/fields) }\end{array}$ & $88(88 \%)$ & $12(12 \%)$ & $0(0 \%)$ \\
\hline 24 & $\begin{array}{l}\text { Do you wear long pants when working in the fields/gardens/fields to avoid } \\
\text { snake bites? }\end{array}$ & $98(98 \%)$ & $2(2 \%)$ & $0(0 \%)$ \\
\hline
\end{tabular}

According to table 4, it is found that most of the respondents use personal protective equipment when working, which can be seen from the highest answer of respondents to question number 24 that a number of $98(98 \%)$ respondents use long pants when working in the fields, gardens, and fields to avoid snakebite and the remaining $2(2 \%)$ respondents did not do this. The most response of no, there are answers to question number 19 , namely a number of 22 $(22 \%)$ respondents do not use sticks to avoid snakes when doing activities outside the house at night.

Table 5. Frequency and maximize the percentage indicator lighting

\begin{tabular}{clccc}
\hline No & \multicolumn{1}{c}{ Question } & Yes & No & Don't know \\
\hline 7 & $\begin{array}{l}\text { Do you maximize adequate lighting in your home environment and the } \\
\text { field/rice field/garden area where you work? (flashlight, torch, lamp) }\end{array}$ & $100(100 \%)$ & $0(0 \%)$ & $0(0 \%)$ \\
\hline 18 & $\begin{array}{l}\text { Do you use a light/flashlight when you go out at night? (when going to rice } \\
\text { fields, fields, gardens at night) }\end{array}$ & $86(86 \%)$ & $14(14 \%)$ & $0(0 \%)$ \\
\hline
\end{tabular}


From table 5 , it is found that respondents maximize lighting which can be seen from the respondents' answers, namely $100(100 \%)$ respondents have maximized adequate lighting in the home environment and the area where they work and 86 people $(86 \%)$ use lamps/flashlights when they want to work. out of the house at night. The rest is only a small proportion of $14(14 \%)$ respondents who do not use lights/flashlights when they want to leave the house at night.

Table 6. The frequency and the percentage indicator of keeping the environment

\begin{tabular}{clccc}
\hline No & \multicolumn{1}{c}{ Question } & Yes & No & Don't know \\
\hline 1 & $\begin{array}{l}\text { Do you wear protective shoes (boots) when doing activities/working in the } \\
\text { fields/rice fields/gardens? }\end{array}$ & $98(98 \%)$ & $2(2 \%)$ & $0(0 \%)$ \\
\hline 8 & $\begin{array}{l}\text { Do you use a stick to avoid snakes when you are outside at night? (to the } \\
\text { fields/gardens/fields) }\end{array}$ & $97(98 \%)$ & $3(3 \%)$ & $1(1 \%)$ \\
\hline 13 & Do you chase away the snakes with tools? (stick, iron, bamboo) & $68(68 \%)$ & $32(32 \%)$ & $0(0 \%)$ \\
\hline 25 & $\begin{array}{l}\text { Do you wear long pants when working in the fields/gardens/fields to avoid } \\
\text { snake bites? }\end{array}$ & $46(46 \%)$ & $53(53 \%)$ & $1(1 \%)$ \\
\hline
\end{tabular}

From table 6 above, it is found that most of the respondents maintain the cleanliness of the environment. Efforts that are mostly made are routinely maintaining the cleanliness of garden areas, fields, rice fields by cutting grass and long twigs and cleaning scattered leaves so that they do not become snake nests, which were carried out by $98(98 \%)$ respondents and the rest did not do this. Furthermore, the effort that is still low can be seen in the respondents' answers to question number 25 , namely $46(46 \%)$ respondents said there were branches that touched the house.

Table 7. Frequency and percentage indicator did not sleep directly under

\begin{tabular}{clccc}
\hline No & \multicolumn{1}{c}{ Question } & Yes & No & Don't know \\
\hline 2 & $\begin{array}{l}\text { Do you avoid resting on the ground/underground while working in the } \\
\text { fields/gardens/rice fields? }\end{array}$ & $92(92 \%)$ & $8(8 \%)$ & $0(0 \%)$ \\
\hline 11 & $\begin{array}{l}\text { Do you rest on an elevated place/hut/cot when you are at home/rice } \\
\text { field/field/garden? }\end{array}$ & $65(65 \%)$ & $35(35 \%)$ & $0(0 \%)$ \\
\hline 12 & Do you use mosquito nets when sleeping at home? & $26(26 \%)$ & $74(74 \%)$ & $0(0 \%)$ \\
\hline
\end{tabular}

Based on table 7 above, it was found that most of the respondents tried not to sleep directly below to prevent snake bites. It can be seen from the efforts made by the most respondents, namely a number of $92(92 \%)$ respondents avoiding resting on the ground/ground while working and the remaining $8(8 \%)$ respondents not making these efforts. Then the lowest effort was seen from a number of $74(74 \%)$ respondents who did not use mosquito nets when sleeping at home.

Table 8. The frequency and the percentage indicator of health education

\begin{tabular}{|c|c|c|c|c|}
\hline No & Question & Yes & No & Don't know \\
\hline 9 & $\begin{array}{l}\text { use anti-snake charms to repel snakes while working in the } \\
\text { fields/gardens/rice fields }\end{array}$ & $28(28 \%)$ & $57(57 \%)$ & $15(15 \%)$ \\
\hline 21 & Do you try to dodge if you see a snake? & $98(98 \%)$ & $2(2 \%)$ & $0(0 \%)$ \\
\hline 22 & Do you try to get rid of it if you see a snake? & $89(89 \%)$ & $11(11 \%)$ & $0(0 \%)$ \\
\hline 27 & $\begin{array}{l}\text { Have you ever attended counseling about venomous snakes from the local } \\
\text { health workers in your village? }\end{array}$ & $14(14 \%)$ & $86(86 \%)$ & $0(0 \%)$ \\
\hline 28 & $\begin{array}{l}\text { Have you ever attended counseling on snakebite prevention from health } \\
\text { workers? }\end{array}$ & $7(7 \%)$ & $93(93 \%)$ & $0(0 \%)$ \\
\hline
\end{tabular}

According to Table 8 above showed that the majority of respondent lack of health education. Seen from a number of respondents ie $93(93 \%)$ of respondents have never attended counseling about snakebite prevention of health workers and $86(86 \%)$ of respondents who say that they have never attended counseling about venomous snakes from local health authorities. However, a total of 98 people $(98 \%)$ of respondents tried to avoid when they saw a snake. 


\section{DISCUSSION}

\section{Gender}

The results of this study showed that the gender category of farmers in Panti District was more dominantly male than female farmers, namely $85(85 \%)$ of the total number of 100 respondents because work as a farmer is a job that requires strong energy and qualified physical conditions. Thus, tend to be dominated by the male sex. This is in line with research conducted by Kanti et al (2021) which states that in their research, farmer workers are dominated by male sex because working as a farmer is a job that requires a large amount of energy such as hoeing, plowing, and fertilizing.

However, women can also work as farmers because according to research conducted by Putri and Anzari (2021) which states that women in rural areas consider their role in agricultural processing as a form of helping their husbands and for women who do not have husbands with a low economic level require women to work as farmers. to carry out the role as a housewife and a role in fulfilling the family's economy, but for women it is more to work on land. Based on these results, the researcher assumes that male farmers have a higher prevalence than female farmers because working as farmers requires a large amount of energy. However, women can also participate in working as farmers to help improve the economy of their families.

\section{Age}

In this study, the average age of the respondents was 41.01 years. The majority of respondents are 40 years old $(11 \%)$ out of a total of 100 respondents who are still in the productive age category, especially in agriculture. This is supported by research conducted by Suryati et al (2019) which states that the population group aged 15-64 years is included as a productive group. However, there is a slight difference from the results of research conducted by Ochola et al (2018), namely that people aged 16-30 years are mostly active in herding, collecting firewood, and farming. So that researchers assume that the average age of farmers in Panti Subdistrict, which is 41 years, is still classified as a productive age to work, especially in agriculture. In this section, please do not repeat what did you wrote in the introduction, but you should explain what is your finding, support, compare and contrast with previous study. The discussion must be clear and explain the answer of research question. Explain your novelty in discussion section. In addition, you can explain the finding that can contribute to nursing or health sciences. Explore the significance of the results of the study.

\section{Length of work}

Table 2 shows that the results of this study on the length of time working as a farmer showed a median value of 12 with a minimum value of 1 and a maximum value of 40 years. This is in accordance with data presented by BPS (2018) that the majority of Indonesian people, especially in rural areas, work in the agricultural sector from the age of 15 years and over and according to research by Paloma et al. (2020) the productive age of farmers reaches the age of 65 years. So the researcher argues that the length of work as a farmer is not limited because if the farmer has entered an old age, he can use the services of farm laborers to help with his work (Paloma et al., 2020).

\section{Last education}

In this study, it was found that from a total of 100 respondents, the majority of farmers were $40(40 \%)$ with high school education. Research conducted by Sa'diyah (2020) says that the most recent education taken by farmers is elementary school at $59.5 \%$ (Sa'diyah, 2020). According to research by Lubis (2016), formal education is one of the efforts that a person can do to be able to change a person's behavior for the better by means and processes that have been planned. So the researcher assumes that the level of education of farmers in Panti District has increased with a number of $40 \%$ of farmers with high school education, this of course has an impact on knowledge of farmers in Panti village.

\section{Indicator recognizes snake habitat}

The results of this study found that most of the respondents avoided sticking their hands into holes in the ground, piles of wood, and cracks in twigs. This is in line with the research by Dafa and Suyanto (2021) which states that snakes are found in many areas of trees, yards, rice fields, and even in waterways. In previous studies, it was stated that the activities most related to the incidence of snake bites according to respondents were in the fields or fields and farming or gardening activities (Munawwaro, 2020). So the researchers assume that this can be done to prevent farmers from being bitten by snakes when they are active in rice fields, fields, and gardens. According to research by Reza, et al (2017) several places such as cracks or holes in the ground, piles of wood, rocks, and tree areas have the potential to become habitats for snakes so they need to be avoided as an effort to prevent snake bites. This is also justified according to 
Warrel (2010) and WHO (2016) in Priambodo, et al (2020) who mention several strategies to avoid snake bites, namely avoiding snake habitats such as tall grass, swamps, and holes in the ground. However, most of the respondents when they saw and met snakes held or handled them directly. According to research by Muthmainnah (2020) snake bites often occur in the tropics, especially in farmers, most of which are caused by handling and even attacking snakes. By refraining from holding or approaching snakes in the wild is one of the efforts to prevent snake bites (Syed, 2019). In holding and handling snakes, special techniques and abilities are needed to avoid snake attacks. The researcher assumes that the respondent may not know that holding a snake with the wrong technique will harm him.

Most of the respondents already have their own latrine or bathroom at home, but there are still farmers who carry out defecate activities in the river because when they are in the fields, farmers use emergency latrines located near the river. Based on research by Munawwaroh (2020) which explained that some snakes have habitats or like moist and wet areas. The CDC (2018) also explained that efforts that can be made to reduce snake bites are to be aware of water areas where snakes may be looking for food. Researchers assume that this needs to be reduced because in addition to polluting the environment, carrying out MCK activities in rivers is also at risk of direct contact with snakes because rivers or waters are also a habitat for snakes.

In this study, most of the respondents stated that they did not have livestock in the garden or in the field and there was no guardrail between the garden and the house area. According to Afni and Sani (2020) some precautions to avoid being bitten by snakes are to keep the house from rats and do not keep livestock in the house or garden because livestock and rodents are so that snakes are not attracted to come to the area because livestock and rodents are a prey for snakes. One type of snake, namely the Javan cobra (Naja sputatrix) has the ability to adapt well to the human environment because one of the factors is food in the form of rodents which are often found in the human environment (Dafa and Suyanto, 2021). The researcher assumes that some farmers who raise livestock in dry fields, gardens, or houses allow snakes to enter the area because they are interested in finding prey, coupled with the absence of a guardrail between their house and rice fields which are snake habitats, making it easier for snakes to enter the human environment.

\section{Indicator of wearing PPE (Personal Protective Equipment)}

In this study, most of the respondents wore PPE when working in the fields, gardens, and fields. This is supported by previous research which said that most of the snakebite prevention methods known to the respondents were using boots (Munawwaro, 2020). But this is contrary to the research of Wismaningsih and Oktaviasari (2015) explaining that farmers pay less attention to the use of PPE because they object to spending a lot of money to have PPE that is in accordance with standards so that farmers prefer to spend money to increase the economic value of their harvests (Wismaningsih and Oktaviasari, 2015 ). Even though the use of good PPE when working can prevent work accidents, including snake bites. If you are active at night, you should use assistive devices such as sticks or branches to reach something if needed (RSUI, 2019). This is in accordance with Andriyanto's research (2017) that using PPE can prevent to minimize the risk of health and safety hazards caused by work activities (Andriyanto, 2017). According to Sidqi's research (2020) the personal protective equipment that should be used by farmers are work clothes, headgear, nose and mouth protective equipment, gloves, and work shoes. However, in another study it was also stated that there were seven items of complete personal protective equipment for farmers, namely hats, glasses, masks, gloves, shirts and trousers, and boots (Minaka et al., 2016). So the researchers assume that the use of PPE is highly recommended and must be done by farmers when working to avoid the risk of snake bites.

\section{Indicator maximizes exposure}

The results of this study showed that most farmers are aware of the importance of lighting when they are in the home environment or work area, especially when they are active at night. This is supported by previous research which states that some farmers go to the fields to drain water or deliberately work at night so as to allow farmers to be bitten by snakes, and farmers know the time associated with snake bites, namely at night as many as $31 \%$ of respondents (Munawwaro, 2020). According to Wintoko and Prameswari (2020) one of the venomous snakes that needs to be watched out for because this snake is active at night (nocturnal) is the weling snake (Bungarus candidus) which has a lethal neurotoxic effect. Farmers who are active at night need to be aware of snakes that are active at night (nocturnal) such as Bungarus sp. and Acanthopis rugosus so that with adequate lighting it can help when farmers are active both at home and when going to gardens, fields, and rice fields at night thereby reducing direct contact with snakes (Pratama and Oktafany, 2017; Wicaksono et al., 2020). So researchers assume that when working or living in plantation areas, especially at night, it is necessary to pay attention to lighting to determine the presence of snakes that are nesting, coincidentally passing or looking for prey so as to prevent humans from direct contact with snakes and minimize snake bites. 


\section{Indicators of keeping the environment clean}

From this study, it was found that most of the respondents maintained the cleanliness of their home environment and garden areas, fields, and rice fields by routinely cutting grass and shrubs and cutting branches and tree branches that were too long to touch the house. However, most of the respondents said that the landfill was close to their house. This has the potential to become a place for snakes to live because in general snakes are often found and like dirty, damp places, shrubs, piles of dry leaves and twigs, even in trees (Reza et al., 2017). One type of venomous snake that is often encountered by farmers on tree branches and shrubs is the green snake (Trimeresurus albolabris) which has a type of hemotoxin venom (Putra, 2019). According to WHO (2016), keeping the environment clean can prevent rodents such as rats and frogs which are one of the prey for snakes entering the home environment. So the researcher assumes that the actions taken by the farmers are one of the efforts that can be taken to prevent snakes from nesting. And with a clean environment, animals that may become prey for snakes do not enter the home environment so that snakes look for prey elsewhere.

\section{Indicator does not sleep directly under}

Based on the table above, the next indicator, namely not sleeping, is directly below there are 3 question items. Most of the respondents in this study said that they did not sleep or rest on the floor or sit down while resting in the garden. However, there are still a small number of respondents who sleep on the floor or in the garden. Even though sleeping on the floor or garden can potentially be bitten by a snake because according to Putra (2019) several types of snakes are active in bush areas, open grass fields, plantations and environments with flat soil textures that may become temporary resting places for farmers. Some of the above precautions are supported by recommendations from WHO (2016) which states that using raised beds or resting areas and using mosquito nets when sleeping at home is recommended to anticipate threats from snake bites that may enter the house. Because in South Asia, almost all krait (Bungarus) snake bites occur in people sleeping in their homes, usually on the floor but sometimes even in bed and under pillows. So the researchers assumed that sleeping or resting in an elevated place could be a preventive measure to prevent direct contact with snakes and the use of mosquito nets could prevent snakes from entering homes and possibly biting humans while they were sleeping.

\section{Health education indicators}

In this study, it was found that most of the respondents had never attended counseling about snakes and snakebite prevention from local health workers so that there were still a small number of respondents who used snake charms and most of the respondents still tried to repel them if they saw snakes. Based on the information obtained from the Public Health Services of Panti had never held a health education and education regarding snakebite management to farmers. This is supported by previous research which stated that most of the respondents knew prevention methods but were not actually applied at work and believed more in traditional methods for treating snakebite cases (Munawwaro, 2020). These results are similar to other studies conducted in South Asia which stated that the high level of illiteracy and the lack of public awareness and understanding of the types of venomous snakes were one of the factors causing snakebite cases (Ralph et al, 2019). According to Michael (2018), health education is able to improve the management and prevention of snake bites and the materials that can be provided starting from increasing awareness about the importance of snakebite prevention measures and first aid and treatment options used. The importance of providing health education also affects the level of knowledge of respondents about the first treatment of venomous snake bites from what was initially categorized as sufficient to categorized as good after being given health education (Muthmainnah, 2020). Thus, the burden of snakebite morbidity can be reduced by providing area-specific guidelines and training protocols for effective case management. Support materials for health care providers at all levels of health care can help disseminate appropriate scientific knowledge regarding snakebite management (WHO, 2016). So that researchers assume that the provision of health education can affect the behaviour of farmers, especially in terms of prevention and treatment of snake bites. 


\section{CONCLUSION}

From these results it can be concluded that the majority of respondents made several attempts to identify the snake habitat, wear personal protective equipment when working, maximizing lighting, keeping the environment clean and do not sleep directly under that is expected to prevent snake bites.

However, it is necessary to have regular health education from local health workers about venomous snakes and snakebite management to farmers so that farmers' knowledge of venomous snakes can increase and they can take preventive measures recommended by WHO.

\section{ACKNOWLEDGEMENT}

Researchers would like to thank all those who supported this research in particular to institute Research and Community Service (LP2M) Jember University with financial support provided through the Grant Research Group (KeRis) Comprehensive Care of Critical and Emergency Nursing (CARING).

\section{REFERENCES}

Adiwinata, R. \& E. J. Nelwan. (2015). Snakebite in indonesia. Acta Medica Indonesiana. 47(4):358-365.

Afni, A. C. N. \& F. N. Sani. (2020). Pertolongan pertama dan penilaian keparahan envenomasi pada pasien gigitan ular. Jurnal Kesehatan Kusuma Husada. 11(Vol. 11 No. 1, Januari 2020 Section):91-98.

Andriyanto, M. R. (2017). Hubungan predisposing factor dengan perilaku penggunaan apd. The Indonesian Journal of Occupational Safety and Health. 6(1):37.

Bawaskar, H. S. \& P. H. Bawaskar. (2015). Toxicology symposia - review article snake bite poisoning. Journal of Mahatma Ganhdi Institute of Medical Sciences. 20(1):5-14.

CDC. (2018). Natural Disasters and Severe Weather. https://www.cdc.gov/disasters/snakebite.html

Fraenkel, J. R., N. E. Wallen, \& H. H. Hyun. (2012). How to Design and Evaluate Research in Education. Edisi 8th. New York: McGraw-Hill Companies.

Hukum, S. (2017). Pengertian Pencegahan. https://suduthukum.com/2017/04/pengertian-pencegahan.html

Johns Hopkins Medicine. (2019). Snake Bites

Maharani, T. (2018). Pakar: Puluhan Tahun Gigitan Ular Jadi Kasus Terabaikan. https://www.netralnews.com/news/kesehatan/read/121633/pakar-puluhan-tahun-gigitan-ular-jadi-kasus-terabaikan

Masturoh, I. \& N. A. T. (2018). Metodologi Penelitian Kesehatan PUSAT PENDIDIKAN SUMBER DAYA MANUSIA KESEHATAN. Dalam Bahan Ajar Rekam MEdis Dan Informasi Kesehatan (RMIK). KEMENTERIAN KESEHATAN REPUBLIK INDONESIA.

Medikanto, A. R., L. M. M. Vanende Silalahi, \& S. Sutarni. (2017). Viperidae snake bite: kasus serial. Berkala IImiah Kedokteran Duta Wacana. 2(2):361.

Michael, G., I. Aliyu, \& B. Grema. (2019). Primary prevention of snakebite envenoming in resource-limited settings: a narrative review. Environmental Disease. 4(2):37.

Michael, G. C., B. A. Grema, I. Aliyu, M. A. Alhaji, T. O. Lawal, H. Ibrahim, A. G. Fikin, F. S. Gyaran, K. N. Kane, T. D. Thacher, A. K. Badamasi, \& E. Ogwuche. (2018). Knowledge of venomous snakes, snakebite first aid, treatment, and prevention among clinicians in northern nigeria: a cross-sectional multicentre study. Transactions of the Royal Society of Tropical Medicine and Hygiene. 112(2):47-56.

Minaka, I. A. D. A., A. A. S. Sawitri, \& D. . Wirawan. (2016). Hubungan penggunaan pestisida dan alat pelindung diri dengan keluhan kesehatan pada petani hortikultura di buleleng , bali association of pesticide use and personal protective equipments with health complaints among horticulture farmers in buleleng, bali. Public Health and Preventive Medicine Archive. 4(1):94-103.

Munawwaroh, F. (2020). Pengetahuan Tentang Pencegahan Dan Penanganan Gigitan Ular Pada Petani Di Kecamatan Panti Kabupaten Jember. Jember: PROGRAM STUDI ILMU KEPERAWATAN FAKULTAS KEPERAWATAN UNIVERSITAS JEMBER.

Mustafa, M., K. Fairrul, E. Illzam, H. Firdaus, A. Nornazirah, \& H. Mehvish. (2016). Neurotoxicity related to snakebite : treatment , and prevention. Journal of MEdical and Dental Science Research. 3(10):20-25.

Notoatmodjo, S. (2012). Metodologi Penelitian Kesehatan. Jakarta: PT RINEKA CIPTA.

Nursalam. (2017). Metodologi Penelitian IImu Kperawatan: Pendekatan Praktis. Edisi Edisi 4. Jakarta: Salemba Medika.

Ochola, F. O., M. O. Okumu, G. M. Muchemi, J. M. Mbaria, \& J. K. Gikunju. (2018). Epidemiology of snake bites in selected areas of kenya. Pan African Medical Journal. 29:1-14.

Paloma, C., Yusmarni, A. Su. Utami, \& Hasnah. (2020). Pengaruh aksesibilitas pembiayaan terhadap pendapatan petani kopi di lembah gumanti kabupaten solok. Jurnal Agrisep. 19(2):301-314.

Polit, D. F. \& C. T. Back. (2014). Essentials of Nursing Research Seventh Edition Appraising Evidence for Nursing Practice, Lippincott Williams \& Wilkins.

Pratama, G. Y. \& Oktafany. (2017). Gigitan ular pada regio manus sinistra. Journal Medula Unila. 7

Pratiska, I. G. P. A., I. B. M. Suaskara, J. Wiryatno, \& I. G. A. P. Putra. (2017). Inventarisasi jenis - jenis ular yang ditemukan di 
sekitar pantai merta sari dan padang galak. SIMBIOSIS Journal of Biological Sciences. 5(2):69.

Putra, D. D. K. (2019). Gambaran Kasus Kejadian Gigitan Ular Di Instalasi Gawat Darurat Rumah Sakit Perifer Di Jember (Retrospective Study Tahun 2016-2017). Jember: Universitas Jember.

Rahadian, R. (2012). Managemen Penanganan Gigitan Ular. 4. Development.

Ralph, R., S. K. Sharma, M. A. Faiz, I. Ribeiro, S. Rijal, F. Chappuis, \& U. Kuch. (2019). The timing is right to end snakebite seaths in south asia. BMJ (Online). 364:1-6.

Reza, F., D. H. Tjong, \& W. Novarino. (2017). Karakteristik morfologi ular familia elapidae di kampus universitas andalas limau manih padang. Sainstek : Jurnal Sains Dan Teknologi. 8(2):135.

Rifaie, F., T. Maharani, \& A. Hamidy. (2017). Where did venomous snakes strike ? a spatial statistical analysis of snakebite cases in bondowoso regency, indonesia. HAYATI Journal of Biosciences. 24(3):142-148.

RSUI. (2019). Wabah Ular. https://rs.ui.ac.id/umum/berita/wabah-ular

Sa'diyah, S. H. (2020). Hubungan Tingkat Pengetahuan Dengan Perilaku Diet Pada Petani Dengan Kejadian Hipertensi Di Kecamatan Panti Kabupaten Jember. Universitas Jember.

Sidqi, I. N. (2020). Hubungan Perilaku Dengan Kecelakaan Kerja Pada Petani Di Kelurahan Antirogo Kecamatan Sumbersari Kabupaten Jember. Universitas Jember.

Subroto, H. \& L. Lismayanti. (2017). Snake-bite with disseminated intravascular coagulation (dic) and stage ii hypertension. Journal Of Medicine \& Health. 1(5)

Sugiyono. (2017). Statistika Untuk Penelitian. Bandung: Penerbit Alfabeta.

Susanto, T., R. Purwandari, \& E. W. Wuryaningsih. (2016). Occupational health nursing model-based agricultural nursing: a study analyzes of farmers health problem. Journal Ners. 11:45-50.

Syed, A. (2019). Snake bites problem in over the world. 5(February):16-19.

WHO. (2016). Guidelines for the Management of Snakebites. Edisi 2nd Editio.

WHO. (2018). Global Snakebite Burden. March.

WHO. (2019). SNAKEBITE ENVENOMING A Strategy for Prevention and Control

Wicaksono, A., K. Madang, \& E. Dayat. (2020). Identifikasi jenis-jenis ular di desa muktijaya kecamatan muara telang kabupaten banyuasin dan sumbangsihnya pada pembelajaran biologi sma/ma. Bioilmi. 6(1):1-10.

Wintoko, R. \& N. P. Prameswari. (2020). Manajemen gigitan ular update management of snake bite. 4:45-52.

Wismaningsih, E. R. \& D. I. Oktaviasari. (2015). Factors related the used of personal protective equipment in farmers in ngantru tulungagung district. Jurnal Wiyata. 2(2):102-107.

Yunanto, R. A. \& Sulistyorini, L. (2021) 'A Descriptive Study Of Snakebite Victims At Two Public Hospitals Of Jember', Jurnal Kesehatan dr. Soebandi, 9(2), pp. 106-114. 